$p$-ISSN 1693-9484, $e$-ISSN : 2621-8313

Majalah Ilmiah Bahari Jogja (MIBJ)

Vol. 18 No. 1, Februari 2020 (23-36)

DOI : $10.33489 /$ mibj.v18i1.226

(C) 2020 Sekolah Tinggi Maritim Yogyakarta

\title{
Kinerja Operator dan Kehandalan Alat HMC Terhadap Produktivitas Bongkar Muat Curah Kering
}

\author{
Sumarzen Marzuki ${ }^{1 *}$, Fransuskus Yanceanus Wair ${ }^{{ }^{*}}$ \\ ${ }^{1,2}$ STIA dan Manajemen Kepelabuhanan (STIAMAK) Barunawati Surabaya, Jl. Perak \\ Barat No. 173 Surabaya, Indonesia \\ * Corresponding Author. Email: sumarzen.marzuki@me.com Telp : 0811346903
}

\begin{abstract}
Abstrak
Penelitian ini meneliti adanya pengaruh kinerja operator dan kehandalan alat HMC terhadap produktivitas bongkar muat curah kering di perusahaan bongkar muat, objek penelitian ini adalah PT. Peindo III Cabang Tanjung Perak Divisi Peayanan Terminal Jamrud. Populasi penelitian adalah seluruh pegawai operasional Terminal Jamrud yang berjumlah 128 pegawai. Jumlah sampel yang ditarik dari populasi sebanyak 56 orang dan penelitian ini menggunakan metode kuantitatif dan teknik analisis regresi linear berganda. Hasil penelitian menyebutkan bahwa kinerja operator dan kehandalan alat HMC secara parsial dan simutan memiiki pengaruh positif dan signifikan terhadap produktivitas bongkar muat curah kering di Divisi Pelayanan Terminal Jamrud. Jika kinerja operator HMC meningkat maka produktivitas yang dihasikan akan meningkat dan jika alat Harbour Mobile Crane (HMC) semakin handal maka produktivitas akan terus maksimal dan meningkat. Variabel kinerja operator memiliki pengaruh yang paling besar dibandingkan dengan kehandalan alat HMC.
\end{abstract}

Kata Kunci: Kinerja Operator, Kehandalan Alat HMC, dan Produktivitas Bongkar Muat Curah Kering

This study examines the influence of operator performance and the reliability of HMC tools on the productivity of dry bulk loading and unloading companies, the object of this study is PT. Peindo III Tanjung Perak Branch Jamrud Terminal Services Division. The research population was all 128 Jamrud Terminal operational employees. The number of samples drawn from a population of 56 people and this study uses quantitative methods and multiple linear regression analysis techniques. The results of the study stated that the operator performance and reliability of HMC equipment partially and simultaneously had a positive and significant effect on the productivity of the dry bulk loading and unloading at the Jamrud Terminal Service Division. If the performance of HMC operators increases, the productivity produced will increase and if the Harbor Mobile Crane (HMC) tool is more reliable the productivity will continue to be maximal and increase. The operator performance variable has the most influence compared to the reliability of the HMC tool.

Keywords: Operator Performance, HMC Equipment Reliability, and Dry Bulk Loading and Unloading Productivity 


\section{PENDAHULUAN}

PT. Pelabuhan Indonesia III (Persero) cabang Tanjung Perak Surabaya sebagai perusahaan yang bergerak dibidang jasa bongkar muat barang-barang konvensional, yang memiliki gudang penumpukan yang memadai dan diperkenankan untuk bongkar muat dan menumpuk barang-barang yang dibongkar atau yang akan dimuat ke kapal. Sebagai Perusahaan Bongkar Muat (PBM) PT. Pelabuhan Indonesia III (Persero) cabang Tanjung Perak unit Terminal Jamrud bertindak sebagai operator terminal yang khusus melayani pembongkaran dan pemuatan barang- barang konvensional (kargo umum, barang curah kering dan barang curah cair).

Waktu yang dihabiskan kapal selama berada di pelabuhan akan sangat berpengaruh terhadap pengopersian kapal tersebut. Semakin lama kapal berada di pelabuhan, maka pengoperasian kapal tersebut semakin tidak efisien karena biaya yang dikeluarkan semakin tinggi dan akan merugikan pihak-pihak yang terkait. Hal ini akan mempengaruhi produktivitas bongkar muat barang yang akan dilakukan. Ada beberapa faktor yang menyebabkan produktivitas bongkar muat tersebut mengalami peningkatan atau bahkan penurunan yaitu antar lain, kinerja dari sumber daya manusia (operator), dan peralatan yang digunakan dalam mendukung kegiatan bongkar muat (HMC).

Dalam meningkatkan pelayanan yang baik, maka perusahaan dituntut untuk dapat mencapai produktivitas yang tinggi. Untuk memenuhi standar yang telah ditetapkan perusahaan, maka perlu dibuatkan suatu prosedur mengenai proses bongkar muat untuk mempermudah dan mengefisienkan proses bongkar muat di pelabuhan. Tujuan dibuatnya prosedur tersebut diharapkan agar dalam proses bongkar muat dapat berjalan sesuai dengan prosedur yang telah ada dan dapat berjalan dengan mestinya. Oleh sebab itu kinerja operator dan kehandalan alat akan berpengaruh terhadap produktivitas bongkar muat. Semakin baik kinerja operator maka produktivitas yang dihasilkan akan semakin besar demikian juga sebaliknya. Semakin handal sebuah alat yang digunakan maka, produktivitas yang dihasilkan akan semakin besar, demikian juga sebalikny. Dengan latar belakang permasalahan tersebut, penulis ingin melakukan penelitian dengan judul "Kinerja Operator dan Kehandalan Alat Harbour Mobile Crane (HMC) Terhadap Produktivitas Bongkar Muat Curah Kering Pada Terminal Jamrud”.

\section{KAJIAN LITERATUR}

\section{Pengertian Kinerja}

Menurut Anwar Prabu Mangkunegara (2013), istilah kinerja berasal dari kata Job Performance atau Actual Performanse (prestasi kerja atau prestasi sesungguhnya yang dicapai oleh seseorang), maka pengertian kinerja adalah hasil kerja secara kualitas dan kuantitas yang dicapai oleh seseorang pegawai dalam melaksanakan tugasnya sesuai dengan tanggung jawab yang diberikan kepadanya. Kinerja (prestasi kerja) dapat didefinisikan, hasil kerja yang dicapai oleh pekerja atau karyawan secara kualitas dan kuantitas yang sesuai dengan tugas dan tanggung jawab mereka. 
Menurut S.P. Hasibuan (2002) dalam (Mulyadi, 2016) ,mengemukakan kinerja (preastasi) adalah suatu hasil kerja yang dicapai seseorang dalam melaksanakan tugas-tugasnya yang dibebankan kepadanya yang didasarkan atas kecakapan, pengalaman kesungguhan. Menurut Maier (1961) dalam (Soekidjo Notoamodjo, 2015) kinerja adalah kesuksesan seseorang dalam melaksanakan suatu pekerjaan yang dibebankannya. Dalam Soekidjo Notoamodjo (2015), kinerja adalah apa yang dikerjakan oleh seseorang sesuai dengan tugas dan fungsinya.

Kesimpulannya adalah kinerja merupakan hasil output dari perilaku dan tindakan seseorang dalam melakukan pekerjaanya, ia dapat menghasilkan kinerja yang positif dan negatif, semua itu dapat di nilai baik oleh dirinya sendiri, rekan kerja maupun atasan.

\section{Faktor Faktor Yang Mempengaruhi Kinerja}

Dalam Soekidjo Notoamodjo (2015), faktor-faktor yang menentukan kinerja seseorang, dikelompokan menjadi tiga faktor utama, yaitu:

1. Variabel individu, yang terdiri dari: pemahaman terhadap pekerjaanya, pengalaman kerja, larat belakng keluarga, tingkat social ekonomi, dan faktor demografi (umur, jenis kelamin, etis, dan sebagainya).

2. Variabel organisasi, yang anatara lai terdiri dari: kepemimpinan, desain pekerjaan, sumber daya lian, struktur organisasi, dan sebagainnya.

3. Variabel psikologi, yang terdiri dari presepsi terhadap pekerjaan, sikap terhadap pekerjaan, motivasi, kepribadian, dan sebagainnya.

\section{Pengertian Operator}

Menurut Lasse (2014) Operator alat bongkar muata adalah orang yang berkemampuan dan memiliki ijin untuk mengoperasikan peralatan bongkar mua tertentu.

\section{Harbour Mobile Crane}

Harbour Mobile Crane (HMC) adalah jenis shore crane atau derek ponopang yang dirancang khusus untuk diperlukan pelayanan bongkar muat di dermaga. Sistem gantry menggunakn roda dan ban karet (wheel) untuk memudahkannya dalam monouver. Untuk keperluan pelayanan bongkar muat tersebut dibutuhkan peralatan tambahan seperti Grab.

\section{Kehandalan Alat (Reliability) dan Keterawatan (Maintainability)}

Kehandalan dan keterawatan peralatan angkut pada kegiatan operasi pelabuhan merupakan tolak ukur daya tahan (edurance) alat untuk dapat dioperasikan tanpa gangguan atau kejadian yang berarti dan kemudiaan melakukan pemulihan gangguan dalam dimensi waktu, diekspresikan secara kuantitatif dalam formula Mean Time Between Failure (MTBF) dan di formulasikan sebagai Mean Time To Repair (MTTR).

\section{Pengertian Produktivitas}

Pengertian produktvitas dapat didefinisikan, merupakan hasil kerja seeorang atau karyawan yang membandingkan antara input dan output. Menurut Edy Sutrisno (2014), mengemukakan bahwa produktivitas adalah ukuran efisiensi produktif suatu perbandingan antara hasil keluaran dan masukan. Menurut 
Tohardi (2002) dalam bukunya (Edy Sutrisno 2014), mengemukakan bahwa produktivitas kerja merupakan sikap mental. Sikap mental yang selelau mencari perbaikan terhadap apa yang telah ada.

Menurut Sutrisno (2011) secara teknis produktivitas pada dasarnya adalah mencakup sikap mental yang selalu mempunyai pandangan bahwa kehidupan hari ini harus lebih baik dari hari kemarin. Menurut Kussrianto (1990), dalam bukunya (Edy Sutrisno 2014), mengemukakan bahwa produktivitas adalah perbandingan antara hasil yng dicapai dengan peran satu tenaga kerja per satuan waktu.

\section{Faktor-Faktor Yang Mempengaruhi Produktivitas}

Menurut Tuffin dan Cormik (dalam Siagian, 2003) dalam bukunya (Edy Sutrisno, 2014) mengatakan bahawa faktor-faktor yang mempengaruhi produktivitas dapat disimpulakn menjadi 2 (dua) golongan yaitu, faktor yang ada pada diri individu dan faktor yang ada diluar individu.

1. Faktor yang ada pada diri individu yaitu: umur, kedaan fisik individu, kelelahan dan motivasi.

2. Faktor yang ada diluar individu yaitu: kondisi fiskik seperti suara, penerangan, waktu istirahat, lama kerja, upah, bentuk organisasi, lingkungan social dan keluarga.

\section{Pengertian Bongkar Muat}

Kegiatan bongkar muat adalah kegiatan membongkar barang-barang impor dan atau barang-barang antar pulau atau interinsuler dari atas kapal dengan menggunakan crane dan sling kapal ke darat terdekat di tepi kapal, yang lazim disebut dermaga, kemudiaan dari dermaga dengan menggunakan roli, forklift, atau kereta dorong, dimasukan dan ditata ke dalam gudang terdekat yang ditunjuk oleh Administrator Pelabuhan

Menurut Keputusan Manteri Perhubungan No. 33 tahun 2001 Kegiatan Bongkar Muat adalah kegiatan bongkar muat barang dari dan atas ke kapal meliputi kegiatan pembongkaran barang dari palka kapal ke atas dermaga di lambung kapal atau sebaliknya.

Mengacu pada beberapa pengertian diatas dapat disimpulkan bahwa bongkar muat adalah suatu proses kegiatan pemindahan barang dari dan ke atas kapal dengan menggunakan alat bongkar muat barang tersedia di Pelabuhan tempat kegiatan bongkar muat itu dilaksanakan.

\section{METODE PENELITIAN}

\section{Jenis Penelitian}

Jenis peneitian yang penuils gunakan adalah kuantitatif dengan teknik Analisis Regresi Linear Berganda. Peneitian ini bertujuan untuk mengetahui pengaruh antara variabel Kinerja Operator $\left(\mathrm{X}_{1}\right)$ dan kehandalan alat HMC $\left(\mathrm{X}_{2}\right)$ terhadap Produktivitas Bongkar Muat Curah Kering (Y).

Beberapa variable yang akan penulis teliti yaitu:

1. Varibel independen $1\left(\mathrm{X}_{1}\right)$ : kinerja operator dengan indikatornya Kualitas kerja, Kuantitas kerja, Ketepatan waktu. Variabel independen $2\left(\mathrm{X}_{2}\right)$ kehandalan alat HMC dengan indikator Tingkat penggunaan alat (Utilization), Kesiapan alat (Availability), Kehandalan alat (Reability) 
2. Variabel dependen (Y) Produktivitas bongkar muat curah kering dengan indikator Efektivitas, Efisiensi.

\section{Populasi}

Menurut Sugiyono (2011), poplasi adalah wilayah generalisasi yang terdiri dari subjek atau objek yang mempunyai kulaitas dan karakteristik tertentu yang ditetapkan oleh peneliti untuk dipelajari dan kemudiaan ditarik kesimpulannya. Populasi dalam penelitian ini adalah seluruh pegawai operasional Terminal Jamrud yang berjumlah 128 pegawai.

\section{Teknik Pengambilan Sampel}

Pengambilan sampel pada penelitian ini menggunakan rumus Solvin didapatkan hasil perhitungan dalam penelitian ini adalah sebanyak 56 responden untuk mewakili jumlah populasi dan mendapat data yang akurat menggunakan random sampling.

\section{Teknik Pengumpulan Data}

a. Observasi

Pengumpulan data tahap pertama pada penelitian ini yaitu melakukan observasi. Menurut Sutrisno Hadi dalam Sugiyono (2013), observasi merupakan proses yang kompleks, suatu proses yang tersusun dari berbagai proses biologis dan psikologis. Dua diantara yang terpenting adalah prosesproses pengamatan dan ingatan. Jadi pada tahap pertama penulis melakukan observasi masalah kinerja operator dan kehandalan alat HMC terhadap produktivitas bongkar muat curah kering pada Terminal Jamrud.

b. Kuesioner

Menurut Sugiyono (2010), kuesioner merupakan teknik pengumpulan data dengan cara memberikan seperangkat pernyataan atau pertanyaan tertulis kepada responden untuk menjawabnya. Dalam skala pengukuran, penelitian ini menggunakan skala likert, dimana setiap responden mengisi setiap jawaban dari setiap pernyataan yang diberikan dengan tingkatan gradasi sangat positif hingga sangat negatif (sangat setuju, setuju, tidak setuju, sangat tidak setuju).

c. Dokumentasi

Dokumentasi merupakan catatan peristiwa yang sudah berlalu. Dokumentasi bisa berbentuk tulisan, gambar, atau karya-karya momentum seseorang. Dokumen yang berbentuk tulisan misalnya catatan harian, sejarah kehidupan, ceritera, biografi, peraturan kebijakan. Dokumen yang berbentuk gambar misalnya foto, gambar hidup, sketsa, dan lain-lain. Dokumen yang berbentu karya misalnya karya seni yang dapat berupa gambar, patung, film, dan lainlain. Studi dokumen merupakan pelengkap dari penggunaan metode observasi dan kuesioner dalam penelitian kuantitatif (Sugiyono, 2013). Berdasarkan hal itu penulis mengambil teknik pengumpulan data melalui pencatatan secara langsung pada dokumen perusahaan yang ada hubungannya dengan masalah yang diteliti. Data-data yang diperlukan seperti : Gambaran umum perusahaan dan Visi dan Misi Perusahaan

d. Wawancara

Menurut Esterberg dalam Sugiyono (2013) wawancara merupakan pertemuan dua orang untuk bertukar informasi dan ide melalui tanya jawab, sehingga 
dapat dikontruksikan makna dalam suatu topik tertentu. Pada penelitian ini penulis mengumpulkan data melalu teknik wawancara pada berbagai pihak tentang pengaruh kinerja operator dan kehandalan alat HMC terhadap produktivitas bongkar muat curah kering.

e. Studi Pustaka

Penulis menggunakan beberapa teori dari literatur-literatur yang berhubungan dengan kinerja operator dan kehandalan alat HMC tehadap produktivitas bongkar muat curah kering.

\section{Teknik Analisis Data}

Analisis data adalah proses mencari dan menyusun secara sistematis data yang diperoleh dari hasil wawancara, catatan lapangan, dan dokumentasidengan cara mengor ganisasikan data ke dalam kategori, menjabarkan ke dalam unit-unit, melakukan sintesa, menyusun kedalam pola, memilih nama yang penting dan yang akan di pelajari, dan membuat kesimpulan sehingga mudah dipahami oleh diri sendiri maupun orang lain (Sugiyono, 2011). Adapun metode yang digunakan dalam penelitian ini adalah analisis regresi linear berganda, dengan sebelum menguji kualitas data yang diperoleh dengan menggunakan uji validitas dan uji reliabilitas dan menggunakan uji penyimpangan asumsi klasik serta uji hipotesis.

\section{HASIL DAN PEMBAHASAN}

\section{Hasil Analisis Data}

\section{Uji Validitas}

Dalam penelitian ini pengujian validitas hanya dilakukan terhadap 56 responden. Pengambilan keputusan berdasarkan pada nilai $\mathbf{r}_{\text {hitung }}$ (Corrected ItemTotal Correlation) $>r_{\text {tabel }}$ sebesar 0,263, untuk df $=56-2=54 ; \alpha=0,05$ maka item/ pertanyaan tersebut valid dan sebaliknya.

Tabel 1. Hasil Uji Validitas

\begin{tabular}{cccccc}
\hline Butir & $\begin{array}{c}\mathbf{R}_{\text {hitung }} \\
\left(\mathbf{X}_{\mathbf{1}}\right)\end{array}$ & $\begin{array}{c}\mathbf{R}_{\text {hitung }} \\
\left(\mathbf{X}_{\mathbf{2}}\right)\end{array}$ & $\begin{array}{c}\mathbf{R}_{\text {hitung }} \\
(\mathbf{Y})\end{array}$ & $\mathbf{R}_{\text {tabe }}$ & Keterangan \\
\hline 1 & 0,614 & 0,467 & 0,533 & 0,263 & Valid \\
2 & 0,620 & 0,534 & 0,554 & 0,263 & \\
3 & 0,477 & 0,391 & 0,577 & 0,263 & \\
4 & 0,573 & 0,467 & 0,459 & 0,263 & \\
\hline
\end{tabular}

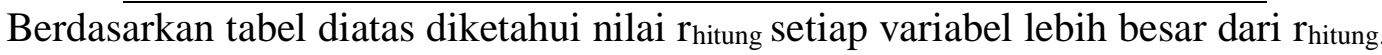
Hal ini dapat dikatakan bahwa jawaban responden pada setiap variabel adalah vaid. 


\section{Uji Reabiitas}

Tabel 2. Hasil Uji Reabilitas

\begin{tabular}{cccc}
\hline Variabel & $\begin{array}{c}\text { Cronbach's } \\
\text { Alpha }\end{array}$ & Kriteria & Keterangan \\
\hline Kinerja Operator $\left(\mathrm{X}_{1}\right)$ & 0.750 & 0.6 & Reliabel \\
Kehandalan Alat HMC $\left(\mathrm{X}_{2}\right)$ & 0.849 & 0.6 & Reliabel \\
Produktivitas Bnngkar Muat & 0.641 & 0.6 & Reliabel \\
Cuarh Kering (Y) & &
\end{tabular}

Pada tabel diatas diketahui bahwa nilai Cronbach's Alpha variabel kinerja operator $\left(\mathrm{X}_{1}\right)$ sebesar 0,750, variabel kehandalan alat HMC $\left(\mathrm{X}_{2}\right)$ sebesar 0,849, dan produktivitas bongkar muat curah kering (Y) sebesar 0,641 lebih besar dari 0,6 artinya seluruh item pernyataan dalam setiap variabel sudah reliabel dalam menjelaskan masing-masing variabel penelitian.

\section{Regresi Linier Berganda}

Tabel 3. Regresi Linear Berganda

\begin{tabular}{ccccc}
\hline Variabel & $\begin{array}{c}\text { Unstandardized } \\
\text { Koefisien } \\
\text { Regresi }\end{array}$ & T & Sig. & Kesimpulan \\
\hline (Constant) & 5,044 & 4,273 &, 000 & \\
Kinerja & 0,483 & 6,398 &, 000 & Signifikan \\
$\begin{array}{c}\text { Operator }\left(\mathrm{X}_{1}\right) \\
\text { Kehandalan }\end{array}$ & 0,336 & 3,146 &, 003 & Signifikan \\
Alat HMC $\left(\mathrm{X}_{2}\right)$ & & & & \\
\hline
\end{tabular}

Kesimpulannya adalah kinerja operator $\left(\mathrm{X}_{1}\right)$ memiliki tingkat singifikansi sebesar $0,000<0,05$ artinya terdapat pengauh anatara variabel kinerja operator tehadap produktivitas bongkar muat curah kering, dan variabel kehandalan alat HMC $\left(\mathrm{X}_{2}\right)$ memiliki tingkat singifikansi sebesar 0,003 $<0,05$ artinya terdapat pengaruh anatara variabel kehandalan alat HMC tehadap produktivitas bongkar muat curah kering.

Persamaan regresi yang terbentuk dalah sebagai berikut:

$$
\mathrm{Y}=5,044+0,483 \mathrm{X}_{1}+0,336 \mathrm{X}_{2}
$$

Variabel kinerja operator $\left(\mathrm{X}_{1}\right)$ memiliki hubungan yang positif terhadap produktivitas bongkar muat curah kering. Artinya semakin baik kinerja operator maka produktivitas bongkar muat curah kering yang dihasilkan akan meningkat. Nilai koefisien regresi kinerja operator sebesar 0,483 artinya setiap kenaikan 1 satuan kinerja operator maka, nilai koefisien produktivitas bongkar muat curah kering aka meningkat sebesar 0,483 dan variabel bebas lain dianggap tetap.

Variabel kehandalan alat HMC $\left(\mathrm{X}_{2}\right)$ memiliki hubungan yang positif terhadap produktivitas bongkar muat curah kering. Artinya semakin handal alat 
yang digunakan maka produktivitas bongkar muat curah kering yang dihasilkan akan meningkat. Nilai koefisien regresi kehandalan alat HMC sebesar 0,336 artinya setiap kenaikan 1 satuan kehandalan alat HMC maka, nilai koefisien produktivitas bongkar muat curah kering aka meningkat sebesar 0366 dan variabel bebas lain dianggap tetap.

\section{Uji Normaitas}

Normal P-P Plot of Regression Standardized Residual

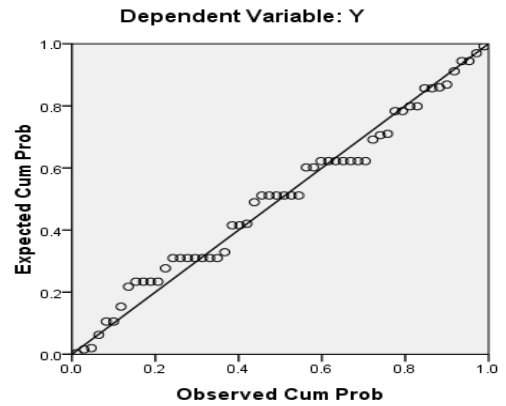

Gambar 1. Hasil Uji Normalitas

Hasil uji normalitas pada gambar grafik terlihat bahwa penyebaran data (titik) pada sumbu diagonal grafik tidak menyebar jauh dari garis diagonal atau mengikuti arah garis diagonal, maka model regresi memenuhi asumsi normalitas.

\section{Uji Mutikoinearitas}

Tabel 4. Hasil Uji Multikolinearitas

\begin{tabular}{|c|c|c|c|}
\hline \multirow{2}{*}{ Variabel } & \multicolumn{2}{|c|}{ Collinearity Statistic } & \multirow{2}{*}{ Keterangan } \\
\hline & Tolerence & VIF & \\
\hline $\begin{array}{c}\text { Kinerja Operator } \\
\left(\mathrm{X}_{1}\right)\end{array}$ & 0,749 & 1,335 & $\begin{array}{c}\text { Tidak Terjadi } \\
\text { Multikolinearitas }\end{array}$ \\
\hline $\begin{array}{c}\text { Kehandalan Alat } \\
\operatorname{HMC}\left(\mathrm{X}_{2}\right)\end{array}$ & 0,749 & 1,335 & $\begin{array}{c}\text { Tidak Terjadi } \\
\text { Multikolinearitas }\end{array}$ \\
\hline
\end{tabular}

Berdasarkan tabel diatas, nilai tolerance semua variabel bebas lebih dari 0,1 dan nilai variance inflation factor (VIF) kurang dari 10. Sehingga dapat diambil kesimpulan bahwa data penelitian ini tidak mengalami multikolinieritas antar variabel bebas.

\section{Uji Heteroskedastisitas}




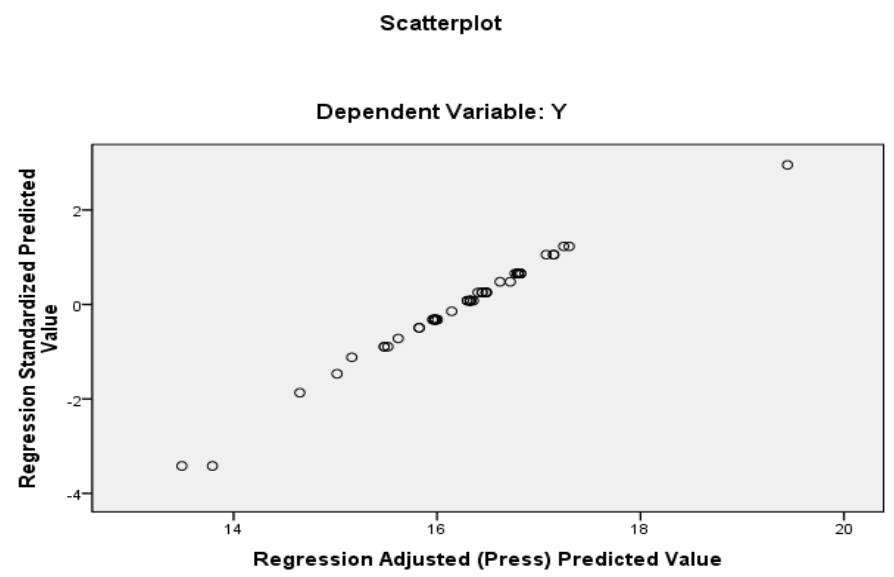

Gambar 2. Hasil Uji Heteroskedastisitas

Hasil uji heteroskedastisitas pada gambar diatas terlihat bahwa scatterplot tidak membentuk suatu pola tertentu serta titik menyebar diatas dan dibawah angka 0 pada sumbu Y maka tidak terjadi heteroskedastisitas.

\section{Uji Linearitas}

Tabel 5. Hasil Uji Linearitas Kinerja Operator $\left(\mathrm{X}_{1}\right)$

\begin{tabular}{lllcc}
\hline & & & F & Sig. \\
\hline Produktivitas & Between & (Combined) & 19.832 & .000 \\
bongkar muat & Groups & Linearity & 96.481 & .000 \\
curah kering & & Deviation from & 4.502 & .002 \\
*kinerja & Linearity & & \\
operator & & & \\
\hline
\end{tabular}

Dari hasil output diatas dapat diketahui bahwa nilai signifikan pada linearity sebesar $0.000<0,05$ maka dapat disimpulkan bahwa antara variabel kinerja operator (X1)mempunyai hubungan yang linear dengan variabel prouktivitas bongkar muat curah kering $(\mathrm{Y})$.

Tabel 6. Hasil Uji Linearitas Kehandalan Alat HMC(X $\left.\mathrm{X}_{2}\right)$

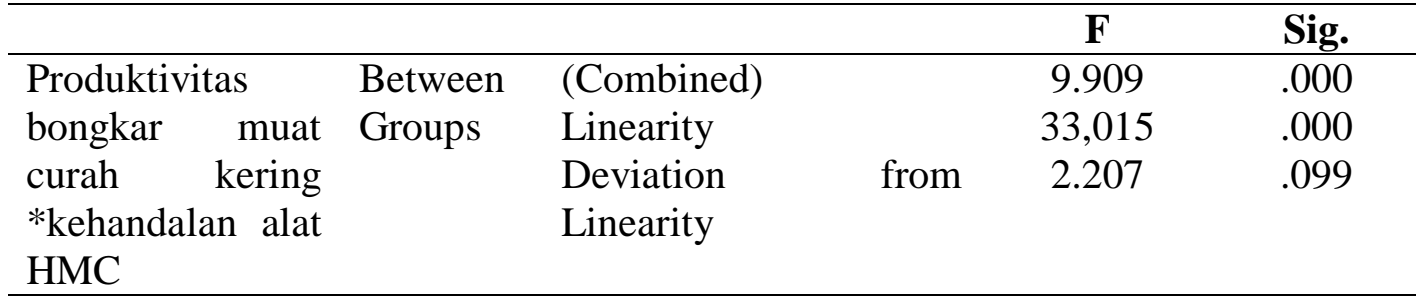

Dari hasil output diatas dapat diketahui bahwa nilai signifikan pada linearity sebesar $0.000<0,05$ maka dapat disimpulkan bahwa antara variabel kehandalan alat HMC $\left(\mathrm{X}_{2}\right)$ mempunyai hubungan yang linear dengan variabel prouktivitas bongkar muat curah kering (Y). 


\section{Anaisis Koefisien Determinasi Berganda}

Tabel 7. Regresi Linear Berganda

\begin{tabular}{lllll}
\hline Mode & R & $\begin{array}{l}\text { R } \\
\text { Square }\end{array}$ & $\begin{array}{l}\text { Adjusted } \\
\text { Square }\end{array}$ & R \\
\hline 1 & $0.801^{\mathrm{a}}$ & 0.641 & 0.628 &
\end{tabular}

Dari tabel diatas, hasil $\mathrm{R}$ sebesar 0.801 menunjukkan bahwa antara kinerja operator dan kehandalan alat terhadap produktivitas adalah kuat adalah kuat, karena nilai $\mathrm{R}$ karena nilai $\mathrm{r}=0,801$ mendekati 1 . Semakin mendekati 1 , semakin kuat.

\section{Uji T}

Berdasarkan hasil uji pada tabe 3 dapat disimpukan:

1. Variabel kinerja operator $\left(\mathrm{X}_{1}\right)$ memiliki hubungan yang signifikan terhadap produktivitas bongkar muat curah kering $(\mathrm{Y})$. Hal ini dapat dibuktikan dengan

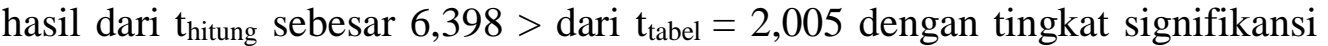
$0,000<0,05$ dan hipotesis $1\left(\mathrm{H}_{1}\right)$ pada penelitian ini diterima.

2. Variabel kehandalan alat $\mathrm{HMC}\left(\mathrm{X}_{2}\right)$ memiliki hubungan yang signifikan terhadap produktivitas bongkar muat curah kering (Y). Hal ini dapat dibuktikan dengan hasil dari thitung sebesar 3,146 lebih besar dari $\mathrm{t}_{\text {tabel }}=$ 2,005 dengan tingkat signifikansi 0,003 $<0,05$ maka dapat disimpulkan bahwa dan hipotesis $2\left(\mathrm{H}_{2}\right)$ dalam penelitian ini diterima.

\section{Uji F}

Tabel 8. Perhitungan uji F

\begin{tabular}{cccc}
\hline Model & F & Sig. & Kesimpulan \\
\hline Regression & 47,382 & $.000^{\mathrm{a}}$ & Signifikan \\
\hline
\end{tabular}

Berdasarkan tabel diatas, diketahui bahwa secara bersama-sama (simultan) variabel kinerja opertaor $\left(\mathrm{X}_{1}\right)$ dan kehandala alat HMC $\left(\mathrm{X}_{2}\right)$ memiliki hubungan yang signifikan terhadap variabel produktivitas bongkar muat curah kering (Y). Hal ini dibuktikan dengan nilai signifikan $F_{\text {hitung }}$ 47,382 lebih besar dari $F_{\text {tabel }}$ 3,17 dan tingkat signifikansi 0.000 lebih kecil 0,05 dan hipotesis $3\left(\mathrm{H}_{3}\right)$ diterima. 
Tabel 9. Variabel Yang Paling Dominan

\begin{tabular}{ccc}
\hline Variabel & Beta & Sig. \\
\hline Constant $)$ & .000 \\
$\begin{array}{c}\text { Kinerja Operator }\left(\mathrm{X}_{1}\right) \\
\text { Kehandalan Alat } \\
\text { HMC }\left(\mathrm{X}_{2}\right)\end{array}$ & 0,608 & .000 \\
\hline
\end{tabular}

Berdasarkan tabel diatas maka diketahui variabel kinerja operator $\left(\mathrm{X}_{1}\right)$ adalah variabel yang memiliki koefisien beta yang paling besar yaitu 0,608 dengan tingkat signifikan $0,000<0,05$. Artinya variabel produktivitas bongkar muat curah kering $(\mathrm{Y})$ lebih banyak dipengaruhi oleh variabel kinerja operator $\left(\mathrm{X}_{1}\right)$ dibandingkan dengan variabel lain. Koefisien yang dimilki oleh variabel kinrja operator $\left(\mathrm{X}_{1}\right)$ bertanda positif, hal ini berarti bahwa semakin baik kinerja operator maka produktivitas bongkar muat curah kering yang dihasilkan akan semakin meningkat.

\section{PEMBAHASAN}

\section{Pengaruh Kinerja Operator $\left(\mathrm{X}_{1}\right)$ Terhadap Produktivitas Bongkar Muat Curah Kering (Y)}

Pelaksanaaan pelayanan jasa terhadap kegiatan bongkar muat menempatkan Sumber Daya Manusia yang terlatih baik dan handal meliputi personil operasi kapal, dermaga, dan operasi lapangan untuk menunjang kelancaran kegiatan bongkar muat dan menjaga produktivitas agar meningkat. Salah satu Sumber Daya Manusia pada kegiatan operasi lapangan adalah operator Harbour Mobile Crane (HMC). Jika kinerja operator baik maka produktivitas bongkar muat curah kering yang dihasikan akan semakin meningkat. Hal ini sesuai dengan penelitian terdahulu yaitu penelitian dari Candra Ladianto (2018) yang menyatakan bahwa kinerja pegawai berpengaruh terhadap produktivitas perusahaan.

Kinerja operator dikatakan baik apabila memenuhi indikator yang ditentukan. Indikator tesebut adalah kualitas kerja, kuantitas kerja, kecepatan, dan tanggung jawab. Kualitas kerja operator dapat dilihat dari seberapa baik seorang operator mengerjakan apa yang seharusnya dikerjakan, jika operator memiiki kualitas kerja yang baik maka produktivitas bongkar muat curah kering yang dihasikan akan meningkat, kuantitas kerja operator dapat dilihat dari seberapa lama operator melaksanakan pekerjaannya dalam sehari, jika semakin lama operator bekerja dalam sehari maka produktivitas bongkar muat curah kering yang dihasikan akan meningkat, kecepatan kerja pada operator dapat dilihat dari seberapa banyak output yang dihasilkan, jika semakin banyak output yang dihasilkan oleh operator maka produktivitas bongkar muat curah kering yang dihasikan akan meningkat dan tanggung jawab dalam melaksanakan pekerjaan yang diberikan, jika operator memiiki tanggung jawab dalam melaksanakan pekerjaan yang diberikan maka produktivitas bongkar muat curah kering yang

Majalah Ilmiah Bahari Jogja 33 | http://jurnal.amy.ac.id/index.php/MIBJ/ 
dihasikan akan meningkat. Menurut Binter dan Zeithmal (2009) untuk meningkatkan performance quality (kualitas kerja) dapat dilakukan oleh perusahaan dengan memberikan pelatihan atau traning.

Berdasarkan hasil penelitian, variabel kinerja operator mempunyai pengaruh positif dan signifikan terhadap variabel produktivitas bongkar muat curah kering. Artinya bahwa semakin baik kinerja operator maka produktivitas bongkar muat curah kering yang dihaslkan akan semakin meningkat. Hal ini sesuai dengan penelitian terdahulu yaitu penelitian dari Benhi M.N Tanuaya (2014) yang menyatakan bahwa pelatihan operator akan meningkatkan produktivitas bongkar muat.

\section{Pengaruh Kehandalan Alat Harbour Mobile Crane (HMC) Terhadap Produktivitas Bongkar Muat Curah Kering}

Sebuah alat dikatakan handal jika alat tersebut beroperasi stabil, konsisten, dan beroperasi secara terus menerus tanpa adanya kerusakan. Jika alat tersebut beroperasi dengan stabil dan konsisten tanpa adanya kerusakan maka produktivitas yang dihasilkan akan besar. Hal ini sesuai dengan penelitian terdahulu yaitu penelitian dari Muhammad Sulaiman (2017) yang menyatakan bahwa tingkat kehandalan alat berat berpengaruh terhadap indeks produktivitas alat berat itu sendiri dan juga pada produksi maupun kinerja perusahaan. Kebutuhan lapangan di dermaga serta jumlah alat bongkar muat yang ada di lapangan juga berpengaruh terhadap produktivitas. Jika kebutuhan lapangan cukup dan banyaknya alat bongkar muat di lapangan yang siap dipakai maka produktivitas yang dihasikan akan meningkat. Hal ini sesuai dengan penelitian terdahulu yaitu penelitian dari Mudjiastuti Handajani (2009) yang menyatakan bahwa sarana penambahan alat bongkar muat diperlukan untuk meningkatkan produktivitas.

Berdasarkan hasil penelitian, variabel kehandalan alat Harbour Mobile Crane (HMC) mempunyai pengaruh positif dan signifikan terhadap variabel produktivitas bongkar muat curah kering. Artinya semakin handal alat tersebut maka produktivitas yang dihasikan akan semakin meningkat. Sesuai dengan kondisi lapangan, kehandalan alat Harbour Mobile Crane (HMC) di Terminal Jamrud dijaga dengan di lakukan perawatan secara berkala serta menggunakan bahan bakar yang berkualitas, karena biaya perawatan dan bahan bakar sebanding dengan produktivitas yang dihasilkan.

Pengaruh Kinerja Operator $\left(\mathrm{X}_{1}\right)$ dan Kehandalan Alat Harbour Mobile Crane (HMC) $\left(\mathbf{X}_{2}\right)$ Terhadap Prodktivitas Bongkar Muat Curah Kering (Y)

Kinerja merupakan hasil atau tingkat keberhasilan seseorang secara keseluruhan selama periode tertentu. Kinerja operator dapat diukur dari output yang dihasikan oleh operator tersebut. Operator dapat mengasilkan output yang baik tidak terlepas dari penggunaan fasilitas yang ada di lapangan. Dalam kegiatan bongkar muat pemakian alat sangatlah diperlukan untuk mempercepat pelaksanaan bongkar muat. Agar kegiatan bongkar muat tersebut bisa selesai dengan biaya, waktu, dan target yang sudah ditentukan maka dibutuhkan operator yang terampil dan tingkat kehandalan alat yang baik untuk meningkatkan produktivitas . Hal ini sesuai dengan penelitian terdahulu yaitu penelitian dari 
Peter L, Barnabas dan Nirmalawanti (2016) yang menyatakan produktivitas tenaga kerja dan utilitas perlatan masih sangat rendah sehingga kehilangan waktu operasi dilapangan sangat besar.

Berdasarkan hasil penelitian, variabel kinerja operator dan kehandalan alat HMC mempunyai pengaruh positif dan signifikan terhadap variabel produktivitas bongkar muat curah kering. Artinya semakin baik kinerja seorang operator dan semakin handal alat yang digunakan maka produktivitas yang dihasilkan akan semakin meningkat. Hal ini sesuai dengan penelitian terdahulu yaitu penelitian dari Nur Widyawati dan Yohanes Purwanto (2018) yang menyatakan bahwa keterampilan operator dan kehandalan alat dapat meningkatkan produktivitas kerja

Variabel kinerja operator $\left(\mathrm{X}_{1}\right)$ memiliki pengaruh paling dominan terhadap produktivitas bongkar muat curah kering. Artinya variabel produktivitas bongkar muat curah kering (Y) lebih banyak dipengaruhi oleh variabel kinerja operator $\left(\mathrm{X}_{1}\right)$ dibandingkan dengan variabel lain. Dalam meningkatkan produktivitas bongkar muat curah kering melalui pengefisienan kinerja operator diadakan pelatihan operator crane. Dengan adanya pelatihan operator crane dapat membentuk TBM (operator HMC) yang mempunyai skill dalam pengoperasian crane sehingga standar produktivitas bongkar muat curah kering tercapai.

\section{SIMPULAN}

1. Kinerja operator $\left(X_{1}\right)$ berpengaruh signifikan terhadap produktivitas bongkar muat curah kering di Terminal Jamrud. Artinya semakin baik kinerja operator maka produktivitas bongkar muat yang di hasilkan juga akan semkain meningkat.

2. Kehandalan alat HMC $\left(\mathrm{X}_{2}\right)$ berpengaruh signifikan terhadap produktivitas bngkar muat curah kering di Terminal Jamrud. Artinya semakin handala alat yang digunakan maka produktivitas yang dihasikan akan semakin meningkat.

3. Kinerja operator $\left(\mathrm{X}_{1}\right)$ dan kehandalan alat $\mathrm{HMC}\left(\mathrm{X}_{2}\right)$ selaku variabel bebas secara simultan atau bersama-sama memiliki korelasi terhadap variabel terikat produktivitas bongkar muat curahkering (Y). artinya semakin baik kinerja operator dan semakin handal alat HMC maka produktivitas bongkar muat yang dihasilkan akan semakin meningkat.

\section{DAFTAR PUSTAKA}

Ahmad Thoardi, (2002). Pemahaman Praktis Manajemen Sumber Daya Manusia, Univeritas Tanjung pura, Mandar Maju, Bandung

Almon Junior Sumanjuntak, (2013). “Aplikasi Data Mining Untuk Pemodelan Pembelian Barang Dengan Menggunakan Alogaritma Apriori. Surabay : Universitas Pembangunan Nasional Veteran".

Arimawanti, (2013). "Pengaruh Kulitas Pelayanan Kinerja Pegawai Administrasi Akademik Terhadap Kepuasan Mahasiswa Fakultas Ekonmi Dan Bisnis Universitas Diponegoro:.

Cornick. Mc dan Tiffin, (2013). Manajemen kinerja. Bandung: Alfabeta 
Davis Keith, (1964). Human Relation At Work;The Dynamiscs of Organizational Behavior. Strcture and Process, Businnes Plubication, Inc. Palno, Texas.

Dermawan, Deni, (2013). Metode Penelitian Kuantitatif. Bandung : PT. Remaja Rosdakarya.

Edy Sutrisno, (2011). Manajemen Sumber Daya Manusia. Jakarta: Kencana

Ghonzali, Imam., (2011). Aplikasi Analisis Multivariate Dengan Program SPSS. Semarang : Badan Penerbit Universitas Dipoegoro.

Hasibuan, (2002). Human resources management revised edition :. Alphabet Earth.

Hoffman, L. R., and N.R.F. Maier, (1961). Quality and Acceptance of Problem Solustions by Members of Homogeneous and Heterogeneous Grups.

Intruksi Presiden Republik Indonesia, (1991). Nomor 3 Tahun 1991 tentang Kebijakan Kelancaran Arus Barang Untuk Menunjang Kegiatan Ekonomi.

Keputusan Manteri Perhubungan, (2001). NOMOR KM 33 TAHUN 2001 Tentang Penyelenggaraan dan Pengusahaan Angkutan Laut.

Keputusan Manteri Perhubungan, (2002). NOMOR KM 14 TAHUN 2002 Tentang Pengusahaan Bongkar Muat Barang Dari dan Ke Kapal.

Kurssianto, (1990). Tranning sumer Daya Manusia yang Efektif. Cetakan 2. Yogyakarta: Erlangga

Lasse, (2014). Keselamatan Pelayaran Dilingkungan Tutorial Pelabuhan dan Pemanduan . Jakarta : Nika

Mangkunegara, Anwar Prabu, (2013). Manajemen Sumber Daya Manusia Perusahan :Remaja Rosdakarya, Bandung

Mc Clelland, D.C, (1987). Human Mitivatioan. New York : Cambridge University Perss.

Mulyadi, (2016). Manajemen Sumber Daya Manusia : In Media

Nur Widyawati dan Yohanes Purwanto, (2018). Keterampilan Operator dan Kehandalan Alat Rubber Tyre Gantry (RTG) Terhadap Produktivitas Kerja. Jurnal Baruna Horizon Volume 1 No. 1. Hal 59 - 72.

Sasono, Herman Budi, (2012). Manajemen Pelabuhan dan Realisasi Ekspor Impor. Yogyakarta: Andi.

Situmorang, Syafizal Helmi dan Muslich Litfi, (2011). Analisis data untuk riset manajemen dan bisnis, Edisi 2, USU Press, Medan.

Sugyono, (2015). Memahami Penelitian Kualitatif. Bandung : Alfabeta

Sunhaji, (2010). Manajemen Kinerja, UPN Press, Jogjakarta.

Sutrisno, Edy, (2014). Manajemen Sumber Daya Manusia : Pernada Media Grup

Suyadi. Prawiresentono, (1999). Manajemen Sumber daya Manusia (Kebijakan Kinerja Karyawan). Kiat Membangun Organisasi Kompetitif Menjelang Perdagangan Bebas Dunia. Edisi Pertama. Yogyakarta;BPFE

Wether Jr., Wiliam B, dan Keith Davis, (2012). Personal Management and HumanResources, New York: Mc. Graw-Hill, Inc.

Zeithaml, Bitner, dan gremler, (2009). Service Marketing: Integrating Customer Focus Across the Firm www.pelindo.co.id 